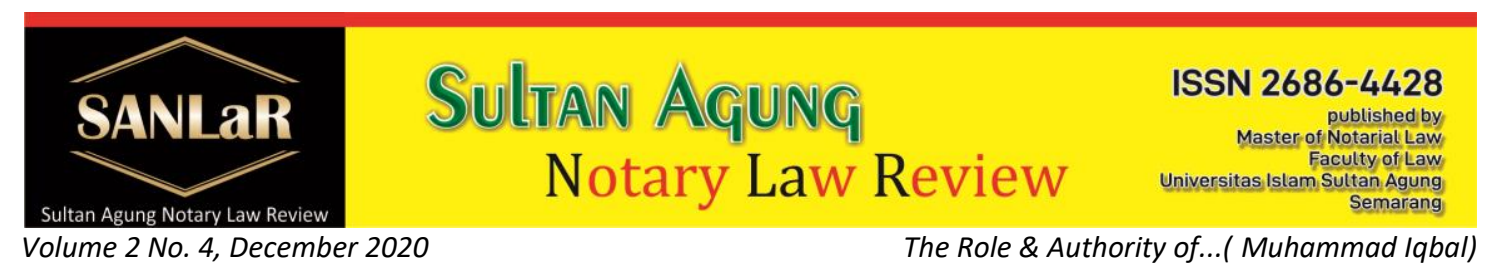

\title{
The Role \& Authority of Inner Notary Making of Heritage Actions
}

Muhammad lqbal $\left.{ }^{*}\right)$

*) Student of Master of Notary Law, Faculty of Law, Universitas Islam Sultan Agung (UNISSULA) Semarang, E-mail: iqbals07@yahoo.com

\begin{abstract}
This study aims to determine the Role and Authority of Notaries in Making the Inheritance Deed and to find out and analyze the obstacles and solutions by the Notary in making the Inheritance Deed. The data used in this study are primary data, secondary data and tertiary data that can support the assessment, which are then analyzed using descriptive analytical methods. Based on the results of data analysis, it can be concluded that: The notary's duty is to formulate the wishes and actions of the parties into an Authentic Deed with due regard to and not violating applicable legal provisions. Authentic Deed as a Deed that has perfect legal force of proof and is binding for the parties, so that the proof can stand alone and do not need to receive assistance and additional other evidence. If any opposing party can prove the Deed is not true with another Otentiuk Deed, then the level of proof of the Authentic Deed may decrease, so that additional evidence is needed. In the making of the inheritance deed, there are several things that are important in the making of the inheritance deed, such as, the parties do not agree, the heir is not legally competent.
\end{abstract}

Keywords: Notary Duties; Authentic Deed; Heir.

\section{Introduction}

Law is a field that cannot be separated from people's life, so that where there is a community there is law (ubi societas ibi ius). The life of a developing community requires legal certainty in the public service sector. One of the jobs that offers services in the legal field, especially civil law is a notary.

The Unitary State of the Republic of Indonesia (NKRI) as a rule of law based on Pancasila and the 1945 Constitution of the Republic of Indonesia (UUD 1945) guarantees legal certainty, order and protection. Guarantee of certainty, order and protection of law in society requires writing as a form or evidence of an act, agreement and legal provision, which has the strongest and fulfilled power of proof. One of the writings that has the strongest and most fulfilling power of proof is the Notary Deed.

Notary Deed is an Authentic Deed, because it is made in the form determined by law and is made by or before a public official who has the authority over it and at the place where the Deed was made. Notary Deed as authentic evidence has an important role in every legal relationship in society, because in the Deed clearly stipulates the rights and obligations of the parties, thus ensuring legal certainty for the community. Notary 
deeds have an important role in every legal relationship in community life, such as in the implementation of inheritance and so on.

In Article 1870 of the Civil Code (KUHP) it is said that an Authentic Deed provides a perfect proof of what is contained in it. Thus, the importance of the Position of Notary in the authority regulated by law is to make a perfect instrument or tool of evidence and therefore an Authentic Deed is in essence deemed correct.

During this period, Notary Public was regulated in the latest Law on Notary Position, namely, Act No. 2 of 2014 concerning the Position of Notary Public. Notary isPublic officials who are authorized to make Authentic Deed and have other powers as referred to in this Law or based on other Laws. Notary's authority is regulated in Article 15 of Act No. 2 of 2014 concerning the Position of Notary:

1. The notary is authorized to make Authentic Deeds regarding all actions, agreements, and stipulations required by the Legislation and/or that the interested party wants to be stated in the Authentic Deed, guarantees the certainty of the date of making the Deed, keeps the Deed, provides Grosse, a copy and excerpts from Deeds, all of which as long as the Deed is drawn up, other officials or other people are not assigned or excluded by law

2. In addition to the authorities as referred to in paragraph (1), the Notary is also authorized:

a. Validate the signature and set the date certainty of the letter under the hand by registering in a special book.

b. Book a letter under hand by registering in a special book. Make a photocopy of the original letter under hand in the form of a copy containing the description as written and described in the letter concerned.

c. Conduct validation of the compatibility of the photocopy with the original letter.

d. Providing legal education in connection with making Deeds.

e. Making deeds relating to land.

f. Make a deed of auction minutes.

When someone is about to enter into a marriage and wants to make an agreement in a marriage, he can use the services of a notary by asking for a marriage certificate. Not only that, even when someone who has a will before he dies can use the services of a notary by asking for a will. In a relationship with someone who has passed away (heir), then a problem arises about what he left behind in the form of property to the person left behind (heir).

Inheritance is an important thing in our life. Not only for ourselves, but also for our future children and grandchildren. Although important, often this inheritance issue raises various problems. Not surprisingly, many people break their ties because of inheritance rights. The main problem is usually differences of opinion regarding equality and fairness. Even though the rules and calculations are quite complicated, we need to think about it from now on and don't try to subordinate it. It is feared that this inheritance will become a big problem that will arise in the future. For that, we need to 
study Inheritance Law in Indonesia. We are also required to understand and understand, so that when the distribution occurs we will reach consensus and there will be no disputes and behind-the-line talk.

Indonesia is a multicultural country, the various existing regulations cannot segment the existing culture. Same goes for the Law of Inheritance. In Indonesia, there is no inheritance law that applies nationally. The existence of Inheritance Law in Indonesia is Customary Inheritance Law, Islamic Inheritance Law, and Civil Inheritance Law. Each inheritance law has different rules, as for the following explanation:

\section{Customary Inheritance Law}

Indonesia is an archipelago which consists of various ethnic groups, religions and customs which are different from one another. This affects the prevailing law in each class of society known as customary law.

Customary law itself is unwritten, only in the form of norms and customs that certain communities in an area must obey and only applies in that area with certain sanctions for those who violate them. Therefore, customary inheritance law is heavily influenced by social or kinship structures.

\section{Islamic Inheritance Law}

Islamic Inheritance Law applies to Indonesian people who are Muslim and is regulated in Articles 171-214 of Islamic Law Compilation, namely Islamic Law material written in 229 Articles. In Islamic Inheritance Law adheres to the principle of Individual and Bilateral inheritance, not Collective or Majorate. Thus the heir can come from the father or mother.

According to Islamic Inheritance Law Article 171 Compilation of Islamic Law, there are three conditions so that inheritance is declared to exist so that it can give a person or heir the right to receive an inheritance:

a. The person who inherits (the heir) has passed away and it can be proven legally that he has died, if there is a distribution or gift of property to the family when the heir is still alive, it is not included in the category of inheritance but is called a grant.

b. People who inherit (heirs) are still alive when the person who inherits dies.

c. People who inherit and inherit have a family relationship or kinship, both straight-line ties such as father or grandfather and straight down relationships such as children, grandchildren, and uncles.

\section{Civil Inheritance Law}

Civil Inheritance Law or what is often called the West Heritage Law applies to nonMuslim communities, including Indonesian citizens of Chinese and European descent, whose provisions are regulated in the Civil Code (KUHP). 
Civil Inheritance Law adheres to an Individual system in which each heir obtains or owns the inheritance according to his own share. In Civil Inheritance Law there are two ways to inherit, namely:

a. Inheritance based on law or inheriting without a will is known as Ab-instentato, while the Inheritor is called Ab-instaat. There are 4 categories of heirs based on the law, namely:

1) Group I consists of husband and wife and children and their offspring.

2) Group II consists of parents and siblings and their offspring.

3) Group III consists of grandparents and so on and above.

4) Group IV consists of families in further lateral lines, including brothers and sisters of Class III Heirs and their descendants.

b. Inherit based on a will, namely in the form of a person's statement about what he wants after his death which the maker can change or revoke as long as he is still alive in accordance with Article 992 of the Civil Code. .

The requirements for making a will apply to those who are 18 years old or over and already married even though they are not yet 18 years old. Included in the class of heirs based on a will are all persons appointed by the heir by means of a will to be his heirs.

Fatwa or heir determination issued by Courts, Religious Courts for Muslims (Article 9 letter b of Act No.3 of 2006 concerning Amendments to Act No.7 of 1989 concerning Religious Courts) and District Courts for religions other than Islam (Article 833 KUHP).

In the case of inheritance, the Notary also prepares a Certificate of Inheritance which is an underhanded Deed and not a Notary Deed and a Certificate of Inheritance (verklaring van erfrecht) made by a Notary is an Inheritance Certificate made for the heirs of citizens or groups of Tiong Hoa descent. and Europe (Letter of the Supreme Court of the Republic of Indonesia dated 8 May 1991 designating a Circular dated 20 December 1969 No. Dpt/12/63/12/69) ${ }^{1}$

The determination of the heir, whether issued by the court (religious or state) or the inheritance deed made by a notary is legally recognized. So, in the event that the Inheritance Expert already has an Inheritance Deed made by a Notary Public, there is no need to ask for an Inheritance from the Court.

\section{Research methods}

The approach method used in this research is that the author uses the Normative Juridical approach, which is a research that deductively begins to analyze the Articles in the Laws and Regulations that govern the above problems. What is meant by juridical legal research is research that refers to existing literature studies or to secondary data used. Meanwhile, Normative Law research is to obtain Normative knowledge about the relationship between one Regulation and another and its application in practice.

\footnotetext{
${ }^{1}$ https://www.hukumonline.com/klinik/detail/ulasan/lt4d9ed1f603631/dasar-hukum-penetapan-warisdan-akta-waris/Accessed on 11 November 2020, 23.15 WIB
} 


\section{Results and Discussion}

\subsection{Role and Authority of Notary in Preparation of Inheritance Deed}

The main task of a notary is to make an authentic deed. As for the word Authentic, based on Article 1870 of the Civil Code (KUHP) it provides the parties who make it a perfect proof. Herein lies the important meaning of a Notary, that because the Law is given the authority to create a perfect means of proof, in the sense that what is stated in the Authentic Deed is in essence deemed true as long as there is no evidence to the contrary. ${ }^{2}$

In carrying out its duties and authority to make the Deed requested by the parties facing him, the Notary must fulfill 4 (four) elements, namely:

1. The Element of Truth,

2. Elements of Authenticity,

3. Completeness Elements,

4. The Element of Clarity.

Regarding the authority that must be held by a Notary as a general official to make an Authentic Deed, a Notary may only operate in an area or territory that is determined by its share and only in that area or jurisdiction he is authorized (Article 18 of Law Number 2 of 2014 concerning amendments on Law Number 30 of 2004 concerning Notary Position). If the Notary makes a Deed outside its jurisdiction, the Deed is invalid.

The authority of a Notary in the Notary Position Law (UUJN), by Habib Adjie is divided into 3 (three) domains of authority, namely: ${ }^{3}$

1. Notary Public Authority

The general authority of a Notary is regulated in Article 15 paragraph (1) of Law Number 2 of 2014 concerning the Position of Notary Public, namely the Notary is authorized to make Authentic Deeds regarding all actions, agreements and decrees required by the Legislation and/or desired by those interested in stated in the Authentic Deed. Guarantee the exact date of quotation of the Deed, all that as long as the act of the Deed is not assigned or excluded to other officials or other people as stipulated by law. Based on the authority that is in the Notary Public as stated in Article 15 of the UUJN and the strength of evidence from the Notary Deed, 2 (two) conclusions can be drawn:

a. The task of the notary is to formulate the wishes and actions of the parties into an authentic deed by taking into account and not violating any applicable legal provisions.

b. Authentic Deed as a Deed that has perfect legal force of proof and is binding for the parties, so that the proof can stand alone and do not need to receive assistance and additional other evidence. If any opposing party can prove the

\footnotetext{
2 http://notarisarief.wordpress.com/2011/05/15/otentisitas-suatu-akta-otentik/, accessed on 27 December 2020 at 13:55 WIB.

${ }^{3}$ Habib Adjie, 2008, Indonesian Notary Law (Thematic Interpretation of Law No.30 of 2004 concerning Notary Position), PT. Refika Aditama, Bandung, p. 78
} 
Deed is incorrect with another Otentiuk Deed, then the level of proof of the Authentic Deed may decrease, so that additional evidence is needed.

2. Notary's Special Authority

The special authority of a Notary is regulated in Article 15 of the UUJN including:

a. Ratify the signature and determine the date of the letter under the hand by registering in a special book.

b. Record letters under hand by registering in a special book.

c. Make a copy of the original letters under hand in the form of a copy that makes a description as written and described in the letter concerned.

d. Conduct validation of the compatibility of the photocopy with the original letter.

e. Provide legal education in connection with making Deeds.

f. Making deeds relating to land.

g. Create Auction Minutes Deed.

3. Notary Authorities To Be Determined Based on Legislation

Notary's authority which will be determined later, is the authority that will emerge and be determined based on the Legislation. In this regard, it is necessary to provide limitations regarding the Legislation, as contained in Article 15 paragraph (3). In addition to the powers referred to in Article 15 paragraph (1) and paragraph (2), Notary Public has other powers regulated by the Legislation.

The authority is used as the basis for the Notary if in the future a Regulation is born which includes a clause that requires the use of an Authentic Deed. The increasing public awareness of the law, the more it will make the community need perfect proof to anticipate and/or solve what will happen in the future. This kind of authority will emerge given the increasing need for an Authentic Deed to serve as a perfect and binding evidence.

As in Article 1 UUJN states that a Notary is a public official who has the authority to make Authentic Deed and has other powers as referred to in this Law or other Laws. What is meant by a Deed is a letter as a sign of evidence that contains the incident which is the basis for a right or engagement, which was made from the beginning on purpose for proof. Proof is one of the steps in the civil case process. Proof is needed because of a denial or denial from the opposing party or to justify a right in dispute. ${ }^{4}$ In this case, there are several roles of the notary in making an inheritance deed:

1. Inheritance Deed or Certificate of Inheritance

Is a certificate of inheritance made by a notary based on the statements of the parties or heirs.

2. Deed Making Requirements

In addition to being a source for authenticity, a Notary Deed is a basis for the legality of the existence of the Notary Deed concerned, with the following conditions:

a. The deed must be drawn up by (door) or in front of (ten overstaan) of a public official. If the Notary Deed contains only what a Notary has experienced and witnessed as a general official, then the deed is called a verbal deed or official deed (ambtelijke akten). One example of official deeds is the deed of minutes

${ }^{4}$ Sudikno Mertokusumo, 1999, Knowing the Law of an Introduction, Liberty, Yogyakarta, p. 124. 
adopted by the Notary of a meeting of shareholders of a limited company. If a deed in addition to making notes about what the Notary witnessed or experienced also contains what was agreed upon or determined by the parties who presented to the Notary Public, then the deed is called "deed partij".

b. The deed must be made in the form prescribed by law. Regarding the form that has been determined by UUJN, the deed consists of the head of the deed, the body of the deed, the end of the deed. The parts of the deed which consist of the head of the deed and the end of the deed are the parts that contain authentic elements, meaning that what is stated in the head of the deed and the end of the deed will determine whether the deed is made in the form determined by law or not.

c. Public officials by or in front of whom the deed is drawn up must have the authority to make the deed. One of the conditions that must be met in order for a deed to be authenticated is the authority of the notary concerned to make the deed.

The requirements that must be met in order for a deed to be called evidence are:

a. The letter must be signed

The need to sign a letter to be called a deed is provided for in Article 1874 of the Criminal Code.

b. The letter must contain events that form the basis of a right or engagement.

So the letter must contain a statement that can be the evidence needed, and the legal event mentioned in the letter must be a legal event which forms the basis of a right or engagement.

c. The letter is intended as evidence.

So the letter was deliberately made as evidence. Pursuant to Article 23 , the provisions of the 1921 Stamp Duty output stipulate, among others: that all signs that are signed which are acted as evidence of actual or civil law conditions are subject to a Fixed Stamp Duty of Rp. 25, -. Therefore, the letter that will be used as a means of evidence in court must be affixed with Sufficient Stamp Duty (currently Rp. 6,000).

In Article 1868 KUHP it can be seen that there are several elements of a deed, including:

a. That the deed was drafted and formalized (verleden) in a legal form.

b. That the deed was made by or in the hands of a public official.

c. That the deed is by or in the hands of the authorized official to make it at the place where the deed was made ${ }^{5}$.

An important element that exists or is involved in the making of the deed is the intention to make the deed and the signature. To be classified in the meaning of deed, the deed must be signed, this signing requirement is contained in Article 1869 of the Criminal Code. Article 1869 of the Criminal Code states that a deed which due to the inability or incompetence of the employees referred to above, or due to a defect in its form, cannot be treated as an authentic deed, but nevertheless has the power as underhand writing if it is signed by the parties. .

${ }^{5} \mathrm{R}$. Soegondo Notodisoerjo, 1993, notarial law in Indonesia, an explanation, second printing, raja grafindo persada, jakarta, p. 42 
Like signatures, in the general public, it is often found that fingerprints are used as a substitute for the signature of a person who cannot put his signature, either because they cannot write (illiterate) or because they are disabled or paralyzed. In this case, the signature will usually be replaced with a fingerprint. In practice and custom, it is not called a fingerprint but only a thumbprint. In Article 1874 paragraph (2) of the Criminal Code it is said that signing a letter under the hand is equivalent to one thumbprint, affixed with a statement dated from a notary public or another official appointed by law from which it turns out that he knows the person who was the stamp. thumb, or that this person has been introduced to him that the contents will have been explained to that person and that after the thumbprint has been affixed before the official. Thus the law stipulates that a thumbprint is equivalent to a signature if it is placed on a deed before a notary or other official, who knows the person facing the said person or has been introduced.

\subsection{Barriers and Solutions in Making an Inheritance Deed}

1. Barriers to making inheritance deeds

In making the inheritance deed, there are several things that are important in making the inheritance deed. According to Ngadino as a Notary and Notary Lecturer at Sultan Agung University, the causes of the obstruction in making the inheritance deed are: ${ }^{6}$

a. The parties disagree

What is meant by disagreement is if the parties or heirs do not agree with the making of an inheritance certificate.

b. Inheritance is not legally competent

When facing a notary for an inheritance deed, heirs are not yet old enough or legally incapable

c. Heirs are saved

In making a certificate of inheritance, there are heirs who are not conveyed in statements by other heirs on the grounds that the heirs are outside the country so they are not mentioned.

d. Provides False Remarks

The heir is not honest in giving statements to the notary in making the inheritance deed.

2. Solution in making a certificate of inheritance

a. In making a certificate of inheritance using a court order

b. The parties or anyone who becomes an heir must be present at the Notary

c. The heirs must be honest in conveying statements so that problems do not occur in the future.

d. Complete the documents that are required to make an inheritance deed

When facing a notary to arrange a certificate of inheritance, there are several procedures that must be prepared or carried, namely:

a. Death Certificate of the heir

b. All heirs must be present

c. Bring identity such as KTP and KK

\footnotetext{
${ }^{6}$ Interview with Notary Ngadino in his office, on November 4, 2020 at 09.00 WIB.
} 


\section{Closing}

\subsection{Conclusion}

The task of the notary is to formulate the wishes and actions of the parties into an authentic deed by taking into account and not violating applicable legal provisions. Authentic Deed as a Deed that has perfect legal force of proof and is binding for the parties, so that the proof can stand alone and do not need to receive assistance and additional other evidence. If any opposing party can prove the Deed is not true with another Authentic Deed, then the level of proof of the Authentic Deed can be reduced, so it is necessary to receive additional evidence, and in the making of the inheritance deed, there are several things that are important in making the inheritance deed, such as, the parties do not agree, the heir is not legally competent, the heir is kept, gives false information

\subsection{Suggestion}

In carrying out their duties, notaries should be based on high professionalism because one of their duties is to serve and protect the public. Therefore, the notary must always improve his abilities in science besides that, the notary must be able to say no to the client if the deed he wants to make is contrary to statutory regulations, morals and public order.

\section{References}

Books:

[1] Habib Adjie. (2008). Indonesian Notary Law (Thematic Interpretation of Act No.30 of 2004 concerning Notary Position). Bandung: PT. Refika Aditama

[2] R. Soegondo Notodisoerjo. (1993). Notarial Law In Indonesia, An Explanation, Second Printing. Jakarta: Raja Grafindo Persada

[3] Sudikno Mertokusumo. (1999). Pengantar IImu Hukum. Yogyakarta: Liberty

Internet:

[1] https://www.hukumonline.com/klinik/detail/ulasan/lt4d9ed1f603631/dasarhukum-penetapan-waris-dan-akta-waris/Accessed on 11 November 2020, 23.15 WIB [2] http://notarisarief.wordpress.com/2011/05/15/otentisitas-suatu-akta-otentik/, accessed on 27 December 2020 at 13:55 WIB

Interview:

Interview with Notary Ngadino in his office, on November 4, 2020 at 09.00 WIB. 